J. Product. \& Dev., 21(3): 289- 300 (2016)

\title{
GROWTH AND YIELD OF Hibiscus sabdariffa AS INFLUENCED BY SOWING DATE AND SEEDS COOLING TREATMENTS
}

\author{
E.G. Ismail \\ Medicinal and Aromatic Plants Section, Horticultural Res. Inst., A.R.C., \\ Egypt.
}

\begin{abstract}
A field study was undertaken to optimize the sowing date under the best seed cooling degree during the tow seasons of 2012 and 2013 for Hibiscus sabdariffa L. in Ismailia, Egypt. The experiment was comprised of sowing times (April, May and June), seed cooling degree (Room, $5^{\circ}$ and $10^{\circ}$ ) and their interactions, aiming to increased yield and better calyxes quality.

Vegetative growth characters (plant height, number of branches, root length, fresh and dry weights of leaves, stem and root), yields (number of flower/plant and dry weight of calyx/plant) and anthocyanin content were best with sowing date in Aprill $3^{\text {th }}$ under of $10^{\circ} \mathrm{C}$ seed cooling and their interaction, during both seasons.

Conclusively, sowing of roselle at early time $\left(13^{\text {th }}\right.$ April) and treated of seeds under $10^{\circ} \mathrm{C}$ was the best treatment for enchanting plant growth, yield of calyx and highest percentage of anthocyanin under sandy soil conditions.

Key words: Hibiscus sabdariffa, sowing date, seed cooling degrees, anthocyanin, calyx yield
\end{abstract}

\section{INTRODUCTION}

Hibiscus sabdariffa L., popularly is known as Roselle, a shrub, belong to family Malvaceae, for delicacy and medicinal properties. It is native in Tropical Eastern Africa and South East Asia and present in the formulation of most aromatic teas consumed in that continent. The calyx is widely used for producing drinks because of its high content of anthocyanins and organic acids (Cissé et al., 2009) as well as flavour and colour additives in the manufacture of jam, liquor, and jellies (Akindahunsi and Olaleye, 2003). The plant is also reported to be antiseptic, aphrodisiac, astringent, cholagogue, demulcent, digestive, purgative and resolvent. It is used as a folk remedy in the treatment of abscesses, bilious conditions, cancer, cough, debility, dyspepsia, fever, hangover, heart ailments, hypertension, and neurosis (Tom et al., 2013). 
Each plant has certain environmental requirements. To attain the highest potential yields a crop must be grown in an environment that meets these requirements. Unfavorable environmental conditions can produce a stress on plants resulting in lower yields. Each kind of crop grows and develops most rapidly at a favorable range of air temperatures. This is called the optimum air temperature range. Sowing time has direct effect on the day and night temperature, day light intensity and photoperiods which affected the flower inductions, fruit size, quality and production.

Proper management of roselle by sowing date is an excellent approach to increase both crop yield and economic benefit. Effects of sowing date on plant yield and other traits varied at locations (Naeve et al., 2004). Environmental conditions associated with late sowing affect crop features related to the capture of radiation and portioning of crop resources. These include less vegetative growth, shorter stems (Boquet, 1990); lower reproductive nodes (Board et al., 1999), and shortening of the reproductive phases (Kantolic and Slafer, 2001).

As for the effect of cooling treatments, Reda et al. (1977) showed that vernalization of Ammi visnaga fruits at 0,3 and $5^{\circ} \mathrm{C}$ (especially $3{ }^{\circ} \mathrm{C}$ ) for 30 days increased the growth of the plant, expressed as dry weight of the different plant organs. Engelen and Erwin (1997) stated that, leaf number below the inflorescence and days to anthesis decreased as vernalization time increased from 0 to 15 days at $6.5^{\circ} \mathrm{C}$ for Raphanus sativus L.Garner and Armitage (1998) revealed that, flower stem length of Aquilegia flabalata plant increased with increasing cooling duration. Also, plants cooled eight or 12 weeks were either larger than or similar in size at flowering to noncooled plants or those cooled four weeks. Dielen et al. (2005)suggested that low temperature at $4{ }^{\circ} \mathrm{C}$ was responsible for the high percentage of bolting of (Cichorium intybus var. Sativum)roots recorded in early-sown plants in the field.

Therefore, the present work aimed to establish sowing date and seed cooling temperature for obtaining the highest yield of vinegar roselle calyxes under Ismailia conditions, Egypt.

\section{MATERIALS AND METHODS}

\section{Plant Materials and Growth Conditions}

The experiment was conducted during the two successive seasons of 2012 and 2013 at the Farm of Agriculture Research Station, EL-Kassassin, Ismailia, Egypt. Seeds of roselle (Hibiscus sabdariffa L.) variety "Sabahia 17"were obtained from Medicinal and Aromatic Plants Department, Horti. 
Res. Inst., Agric. Res. Center, Giza, Egypt. Seeds were sown in sandy soil, each sowing date was planted in 6 rows, $4 \mathrm{~m}$ long and $0.6 \mathrm{~m}$ wide, making an area of $14.4 \mathrm{~m}^{2}$. Hills were $50 \mathrm{~cm}$ apart, 4 seeds per hill, three weeks later then thinned to one plant/hill. The chemical and physical properties of

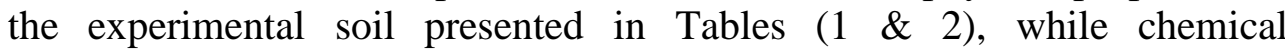
composition of the irrigation water tabulated in Table (3). The experimental design was complete randomized blocks design with 6 replicates in order to evaluate the effects of three sowing dates $\left(13^{\text {th }}\right.$ April, $13^{\text {th }}$ May and $13^{\text {th }}$ June), three seed cooling temperature treatments (Room, $5^{\circ}$ and $10{ }^{\circ} \mathrm{C}$ ) and their interactions, during the two seasons of 2012 and 2013. The seeds of roselle plant were put under cooling treatments throughout 3 weeks before every sowing date. Only one harvest being performed at the end of fructification. Other agricultural practices such as: irrigation and weeding were carried out as recommended.

Table (1): Some chemical properties of the investigated soil.

\begin{tabular}{|c|c|c|c|c|c|c|c|c|c|c|c|c|c|c|}
\hline \multirow{2}{*}{$\begin{array}{l}\text { Depth. } \\
\text { ( cm ) }\end{array}$} & \multirow[t]{2}{*}{$\begin{array}{c}\text { PH } \\
1: 2.5\end{array}$} & \multirow{2}{*}{$\begin{array}{c}\text { E.C. } \\
\text { m. moh } \\
25^{\circ} \mathrm{C} \\
1: 5\end{array}$} & \multicolumn{9}{|c|}{ Meq/L (1:5) } & \multicolumn{3}{|c|}{$\begin{array}{c}\text { Available } \\
\text { mg/100 g Soil }\end{array}$} \\
\hline & & & $\mathbf{K}^{+}$ & SAR & $\mathrm{Na}^{+}$ & $\mathrm{Mg}^{++}$ & $\mathrm{Ca}^{-}$ & $\mathrm{SO}_{4}^{-}$ & $\mathrm{CO}_{3}^{-}$ & $\mathrm{HCO}_{3}^{-}$ & $\mathrm{CL}^{-}$ & $\mathbf{K}$ & $\mathbf{P}$ & $\mathbf{N}$ \\
\hline $0-15$ & 7.9 & 1.66 & -- & 2.50 & 8.00 & 7.46 & 4.68 & 2.46 & 9.97 & 0.85 & 5.28 & 1.40 & 2.04 & 6.08 \\
\hline $15-30$ & 8.1 & 0.86 & - & 2.50 & 2.00 & 4.86 & 3.74 & 1.62 & 3.70 & 0.30 & 2.26 & 1.05 & 1.95 & 4.29 \\
\hline
\end{tabular}

Table (2): Some physical properties of the investigated soil.

\begin{tabular}{|c|c|c|c|c|}
\hline Depth $(\mathbf{c m})$ & Sand \% & Silt \% & Clay \% & Textural class \\
\hline $0-30$ & 83.0 & 14.0 & 3.0 & Sandy \\
\hline $30-60$ & 82.0 & 14.0 & 4.0 & Sandy \\
\hline
\end{tabular}

Table (3): Chemical composition of the experimental water

\begin{tabular}{|c|c|c|c|c|c|c|c|c|c|c|}
\hline \multirow{2}{*}{ 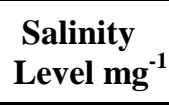 } & \multicolumn{4}{|c|}{ Cations } & \multicolumn{4}{|c|}{ Anions } & \multirow{2}{*}{$\begin{array}{c}\mathrm{EC} \\
\mathrm{dSm}^{-1}\end{array}$} & \multirow{2}{*}{ SAR } \\
\hline & $\mathrm{Ca}^{+2}$ & $\mathrm{Mg}^{+2}$ & $\mathrm{Na}^{+}$ & $\mathbf{K}^{+}$ & $\mathrm{CO}_{3}{ }^{-2}$ & $\mathrm{HCO}_{3}^{-}$ & $\mathrm{SO}_{4}^{-2}$ & $\mathrm{Cl}^{-}$ & & \\
\hline (288) & 1.14 & 1.33 & 1.76 & 0.26 & -- & 2.65 & 0.47 & 1.4 & 0.45 & 1.68 \\
\hline
\end{tabular}

Seed germination started simultaneously six days after sowing, and the germination rate was $100 \%$ in all different sowing dates of Roselle plant during both seasons (data not shown). 


\section{Measurements:}

These were taken on vegetative growth characters on October $13^{\text {th }}$, before harvesting, the following growth criteria were recorded, using eight random plants from each treatment, plant height $(\mathrm{cm})$, number of branches/plant, stem diameter $(\mathrm{cm})$, main root length/plant, fresh and dry weights of leaves, stems and roots/plant $(\mathrm{g})$.

\section{Components of yield}

On December $13^{\text {th }}$, the number of fruits/plant and dry weights of calyx/plant (g) were taken.

\section{Chemical analysis}

Total anthocyanin in dried harvested Roselle calyx was determined by method of Fuleki and Francis (1968) and developed by Du and Francis (1973).

\section{Statistical analysis}

Experiment was set up in randomized complete block design with six replicates per treatment. Data were statistically analyzed using ANOVA \& MANOVA of statistical 6 software (Statsoft, 2001). The significance of differences among means was carried out the Least Significant Test (LSD) at $\mathrm{P}=0.05$.

\section{RESULTS AND DISCUSSIONS}

\section{Plant growth criteria}

Plant height, number of branches, stem diameter and root length were significantly decreased with delaying sowing date in both seasons (Table 4). The first sowing date $13^{\text {th }}$,April gave the highest plant height (178.1 and $170.0 \mathrm{~cm}$ at $1^{\text {st }}$ and $2^{\text {nd }}$ seasons, respectively), number of branches (18.1 and 20.5), stem diameter (4.0and $4.4 \mathrm{~mm}$ ) and root length $(49.9$ and $57.6 \mathrm{~cm}$ ), in 2012 and 2013 seasons, respectively, while the last sowing time $13^{\text {th }}$ June gave minimum measurements in the previous growth characters.

In the same Table the seed cooling degrees treatments gave significant effects in growth criteria. The highest results obtained from the plants cooled its seeds three weeks under $10^{\circ} \mathrm{C}$. This treatment gave the highest plant height $(180.3$ and $172.4 \mathrm{~cm})$, number of branches/plant $(16.0$ and 18.0 ), stem diameter (3.9and $4.5 \mathrm{~mm}$ ) and root length $(48.2$ and $56.6 \mathrm{~cm})$, in $1^{\text {st }}$ and $2^{\text {nd }}$ seasons, respectively

Concerning the effect of the interaction treatments between sowing dates and seed cooling degrees, the data observed in Table (4) reveal that, 
Table (4):Effect of sowing date, seed cooling temperature and their interaction treatments on growth criteria of roselle plants during 2012and 2013 seasons.

\begin{tabular}{|c|c|c|c|c|c|c|c|c|}
\hline \multirow{3}{*}{ (A) } & Room & $5^{\circ} \mathrm{C}$ & $10^{\circ} \mathrm{C}$ & $\overline{M_{A}}$ & Room & $5^{\circ} \mathrm{C}$ & $10^{\circ} \mathrm{C}$ & $\overline{M_{A}}$ \\
\hline & \multicolumn{4}{|c|}{ First season } & \multicolumn{4}{|c|}{ Second season } \\
\hline & \multicolumn{8}{|c|}{ Plant height (cm) } \\
\hline \multirow{3}{*}{$\begin{array}{l}\text { April 13 } 3^{\text {th }} \\
\text { May 13 } 3^{\text {th }} \\
\text { Jun } 13^{\text {th }}\end{array}$} & $167.3 \mathrm{~cd}$ & $168.5 \mathrm{c}$ & $198.5 \mathrm{a}$ & $178.1 \mathrm{a}$ & $157.5 \mathrm{de}$ & $172.5 \mathrm{c}$ & $180.1 \mathrm{a}$ & $170.0 \mathrm{a}$ \\
\hline & $165.0 \mathrm{~d}$ & $166.0 \mathrm{~d}$ & $170.3 \mathrm{bc}$ & $167.1 \mathrm{~b}$ & $137.0 \mathrm{f}$ & $177.0 \mathrm{~b}$ & $177.0 \mathrm{~b}$ & $163.7 \mathrm{~b}$ \\
\hline & $138.6 \mathrm{e}$ & $135.0 \mathrm{f}$ & $172.0 \mathrm{~b}$ & $148.5 \mathrm{c}$ & $140.0 \mathrm{f}$ & $153.5 \mathrm{e}$ & $160.0 \mathrm{~d}$ & $151.2 \mathrm{c}$ \\
\hline $\mathbf{M}_{\mathbf{B}}$ & $157.0 \mathrm{c}$ & $161.5 \mathrm{~b}$ & $180.3 \mathrm{a}$ & & $144.8 \mathrm{c}$ & $167.7 \mathrm{~b}$ & $172.4 \mathbf{a}$ & \\
\hline \multirow{4}{*}{$\begin{array}{l}\text { April 13 } 3^{\text {th }} \\
\text { May } 13^{\text {th }} \\
\text { Jun } 13^{\text {th }}\end{array}$} & \multicolumn{8}{|c|}{ Number of branches (plant) } \\
\hline & $15.7 \mathrm{bc}$ & $17.4 \mathrm{~b}$ & $21.2 \mathrm{a}$ & $18.1 \mathrm{a}$ & $19.0 \mathrm{~b}$ & $20.6 \mathrm{~b}$ & $22.0 \mathrm{a}$ & $20.5 a$ \\
\hline & $12.0 \mathrm{~d}$ & $13.0 \mathrm{~cd}$ & $16.8 \mathrm{~b}$ & $13.9 \mathrm{~b}$ & $14.0 \mathrm{de}$ & $14.7 \mathrm{~d}$ & $16.6 \mathrm{c}$ & $15.1 \mathrm{~b}$ \\
\hline & $8.0 \mathrm{f}$ & $10.0 \mathrm{e}$ & $14.0 \mathrm{c}$ & $10.7 \mathrm{c}$ & $9.0 \mathrm{f}$ & $13.0 \mathrm{e}$ & $15.5 \mathrm{~cd}$ & $12.5 \mathrm{c}$ \\
\hline$\overline{M_{B}}$ & $11.9 \mathrm{c}$ & $13.5 \mathrm{~b}$ & $16.0 \mathrm{a}$ & & $14.0 \mathrm{c}$ & $16.1 \mathrm{~b}$ & $18.0 \mathrm{a}$ & \\
\hline \multirow{4}{*}{$\begin{array}{l}\text { April 13 } 3^{\text {th }} \\
\text { May } 13^{\text {th }} \\
\text { Jun } 13^{\text {th }}\end{array}$} & \multicolumn{8}{|c|}{ Stem diameter $(\mathrm{mm})$} \\
\hline & $3.9 \mathrm{~b}$ & $3.9 \mathrm{~b}$ & $4.3 \mathrm{a}$ & $4.0 \mathrm{a}$ & $4.0 \mathrm{bcd}$ & $4.1 \mathrm{bcd}$ & $5.0 \mathrm{a}$ & $4.4 \mathrm{a}$ \\
\hline & $4.0 \mathrm{~b}$ & $3.9 \mathrm{~b}$ & $3.6 \mathrm{~b}$ & $3.8 \mathrm{a}$ & $3.5 \mathrm{de}$ & $3.9 \mathrm{~cd}$ & $4.3 \mathrm{ab}$ & 3.9 a \\
\hline & $2.9 \mathrm{c}$ & $3.6 \mathrm{~b}$ & $3.7 \mathrm{~b}$ & $3.4 \mathrm{a}$ & $3.1 \mathrm{de}$ & $3.7 \mathrm{cde}$ & $4.1 \mathrm{bcd}$ & $3.6 \mathrm{~b}$ \\
\hline $\mathbf{M}_{\mathrm{B}}$ & $3.6 \mathrm{a}$ & $3.8 \mathrm{a}$ & $3.9 \mathbf{a}$ & & $3.5 \mathrm{~b}$ & $3.9 \mathrm{~b}$ & $4.5 \mathrm{a}$ & \\
\hline \multirow{4}{*}{$\begin{array}{l}\text { April 13 } 3^{\text {th }} \\
\text { May } 13^{\text {th }} \\
\text { Jun } 13^{\text {th }}\end{array}$} & \multicolumn{8}{|c|}{ Root length $(\mathrm{cm})$} \\
\hline & $39.5 \mathrm{f}$ & $53.5 \mathrm{ab}$ & $56.6 \mathrm{ab}$ & $49.9 \mathrm{a}$ & $48.9 \mathrm{~d}$ & $57.5 \mathrm{~b}$ & $66.5 \mathrm{a}$ & $57.6 \mathrm{a}$ \\
\hline & $43.5 \mathrm{~cd}$ & $41.0 \mathrm{de}$ & $45.3 \mathrm{~cd}$ & $43.3 \mathrm{~b}$ & $40.0 \mathrm{e}$ & $52.5 \mathrm{bc}$ & $57.8 \mathrm{~b}$ & $50.1 \mathrm{~b}$ \\
\hline & $33.5 \mathrm{~g}$ & $40.5 \mathrm{de}$ & $42.5 \mathrm{cde}$ & $38.8 \mathrm{c}$ & $32.7 \mathrm{f}$ & $40.3 \mathrm{e}$ & $45.5 \mathrm{de}$ & $39.5 \mathrm{c}$ \\
\hline$\overline{M_{B}}$ & $38.8 \mathrm{c}$ & $45.0 \mathrm{~b}$ & $48.2 \mathrm{a}$ & & $40.5 \mathrm{c}$ & $50.1 \mathrm{~b}$ & $56.6 \mathrm{a}$ & \\
\hline
\end{tabular}

the highest values from the growth criteria obtained from the combined treatment of $13^{\text {th }}$ April and $10 \mathrm{C}$ during the two seasons.

A reduction in plant height by delay sowing time on Roselle plant had already been reported by (Castro et al. 2004). The greater plant height, stem diameter and number of root recorded in $13^{\text {th }}$ April were probably due to comparatively longer growing period along with the optimum environmental conditions, that photoperiod sensitivity had marked reduction in growth period due to delayed seeding might account for decrease (Rahman, 2014) on strawberry.

\section{Fresh and dry weights / plant}

Data presented in Tables (5 and 6) showed that, the sowing date of $13^{\text {th }}$ April gave the greatest fresh and dry weights of leaves, stem and root of roselle plant. These parameters were significantly decreased as a result of 
Table (5): Effect of sowing date, seed cooling temperature and their interaction treatments on fresh weights $(\mathrm{g})$ of leaves, stem and root/plant of Roselle plants during 2012 and 2013 seasons.

\begin{tabular}{|c|c|c|c|c|c|c|c|c|}
\hline \multirow{3}{*}{$\begin{array}{ll}\text { (A) } & \text { (B) } \\
\text { Sowing date }\end{array}$} & Room & $5^{\circ} \mathrm{C}$ & $10^{\circ} \mathrm{C}$ & $\overline{M_{A}}$ & Room & $5^{\circ} \mathrm{C}$ & $10^{\circ} \mathrm{C}$ & $\mathbf{M}_{\mathrm{A}}$ \\
\hline & \multicolumn{4}{|c|}{ First season } & \multicolumn{4}{|c|}{ Second season } \\
\hline & \multicolumn{8}{|c|}{ Leaves (g) } \\
\hline \multirow{3}{*}{$\begin{array}{l}13^{\text {th }} \text { April } \\
13^{\text {th }} \text { May } \\
13^{\text {th }} \text { Jun }\end{array}$} & $316.2 \mathrm{c}$ & 239.4de & $451.8 \mathrm{a}$ & $335.8 \mathrm{a}$ & $398.3 \mathrm{~d}$ & $488.1 \mathrm{c}$ & $559.5 \mathrm{a}$ & $481.9 \mathrm{a}$ \\
\hline & $203.9 \mathrm{f}$ & $335.4 \mathrm{~b}$ & $340.3 \mathrm{~b}$ & $293.2 \mathrm{~b}$ & $94.21 \mathrm{~b}$ & $378.0 \mathrm{~d}$ & $525.6 \mathrm{~b}$ & $332.6 \mathrm{~b}$ \\
\hline & $94.6 \mathrm{~g}$ & $232.4 \mathrm{e}$ & $243.9 \mathrm{~d}$ & $190.3 \mathrm{c}$ & $68.1 \mathrm{~g}$ & $79.99 \mathrm{fg}$ & $292.9 \mathrm{e}$ & $147.0 \mathrm{c}$ \\
\hline$\overline{M_{B}}$ & $204.9 \mathrm{c}$ & $269.1 \mathrm{~b}$ & $345.3 \mathrm{a}$ & & $186.8 \mathrm{c}$ & $315.4 \mathrm{~b}$ & $459.3 \mathrm{a}$ & \\
\hline \multirow{4}{*}{$\begin{array}{l}13^{\text {th }} \text { April } \\
13^{\text {th }} \text { May } \\
13^{\text {th }} \text { Jun } \\
\end{array}$} & \multicolumn{8}{|c|}{ Stem $(\mathrm{g})$} \\
\hline & $591.4 \mathrm{bcc}$ & $612.6 \mathrm{~b}$ & $620.9 \mathrm{a}$ & $608.3 \mathrm{a}$ & $604.4 \mathrm{~d}$ & $657.36 \mathrm{c}$ & $762.98 \mathrm{a}$ & $674.9 \mathrm{a}$ \\
\hline & $436.7 \mathrm{f}$ & $554.3 \mathrm{~d}$ & $572.7 \mathrm{~cd}$ & 521.2 b & $482.67 \mathrm{f}$ & $655.76 \mathrm{c}$ & $715.34 \mathrm{~b}$ & $617.9 \mathrm{~b}$ \\
\hline & $267.6 \mathrm{~g}$ & $456.2 \mathrm{ef}$ & $465.2 \mathrm{ef}$ & $396.3 \mathrm{c}$ & $232.2 \mathrm{~g}$ & $445.85 \mathrm{f}$ & $531.73 \mathrm{e}$ & $403.3 \mathrm{c}$ \\
\hline $\mathbf{M}_{\mathbf{B}}$ & 431.9 b & $541.1 \mathrm{a}$ & 552.9 a & & $439.8 \mathrm{c}$ & $586.3 \mathrm{~b}$ & $670.0 \mathrm{a}$ & \\
\hline \multirow{4}{*}{$\begin{array}{l}13^{\text {th }} \text { April } \\
13^{\text {th }} \text { May } \\
13^{\text {th }} \text { Jun }\end{array}$} & \multicolumn{8}{|c|}{ Roots $(g)$} \\
\hline & $58.2 \mathrm{c}$ & $79.1 \mathrm{~b}$ & $100.2 \mathrm{a}$ & $79.2 \mathrm{a}$ & $62.2 \mathrm{c}$ & $82.3 \mathrm{a}$ & $83.4 \mathrm{a}$ & $76.0 \mathrm{a}$ \\
\hline & $43.4 \mathrm{~cd}$ & $55.9 \mathrm{c}$ & $81.3 \mathrm{~b}$ & $60.2 \mathrm{~b}$ & $56.8 \mathrm{~d}$ & $66.8 \mathrm{bc}$ & $69.2 \mathrm{~b}$ & $64.3 \mathrm{~b}$ \\
\hline & $35.9 \mathrm{~d}$ & $44.6 \mathrm{~cd}$ & $45.8 \mathrm{~cd}$ & $42.1 \mathrm{c}$ & $30.3 \mathrm{e}$ & $57.0 \mathrm{~d}$ & $60.1 \mathrm{~cd}$ & $49.1 \mathrm{c}$ \\
\hline $\mathbf{M}_{\mathrm{B}}$ & $45.8 \mathrm{c}$ & $59.8 \mathrm{~b}$ & $75.7 \mathbf{a}$ & & $49.8 \mathrm{c}$ & $68.7 \mathrm{~b}$ & $70.9 \mathrm{a}$ & \\
\hline
\end{tabular}

Table (6): Effect of sowing date, seed cooling temperature and their interaction treatments on dry weights $(\mathrm{g})$ of leaves, stem and root/plant of Roselle plants during 2012 and 2013 seasons.

\begin{tabular}{|c|c|c|c|c|c|c|c|c|}
\hline \multirow{3}{*}{ Sowing date(B) } & Room & $5^{\circ} \mathrm{C}$ & $10^{\circ} \mathrm{C}$ & $\mathbf{M}_{\mathrm{A}}$ & Room & $5^{\circ} \mathrm{C}$ & $10^{\circ} \mathrm{C}$ & $\mathbf{M}_{\mathrm{A}}$ \\
\hline & \multicolumn{4}{|c|}{ First season } & \multicolumn{4}{|c|}{ Second season } \\
\hline & \multicolumn{8}{|c|}{ Leaves (g) } \\
\hline \multirow{3}{*}{$\begin{array}{l}13^{\text {th }} \text { April } \\
13^{\text {th }} \text { May } \\
13^{\text {th }} \text { Jun }\end{array}$} & $54.3 \mathrm{c}$ & $55.3 \mathrm{c}$ & $77.8 \mathrm{a}$ & $62.5 \mathrm{a}$ & $82.2 b$ & $85.6 \mathrm{~b}$ & $103.1 \mathrm{a}$ & \multirow{3}{*}{$\begin{array}{l}90.3 \mathrm{a} \\
44.6 \mathrm{~b} \\
34.5 \mathrm{c}\end{array}$} \\
\hline & $31.0 \mathrm{e}$ & $45.3 \mathrm{~d}$ & $69.0 \mathrm{~b}$ & $48.4 \mathrm{~b}$ & $25.4 \mathrm{~d}$ & $50.0 \mathrm{c}$ & $58.5 \mathrm{c}$ & \\
\hline & $29.1 \mathrm{e}$ & $32.5 \mathrm{e}$ & $48.3 \mathrm{~d}$ & $36.6 \mathrm{c}$ & $25.0 \mathrm{~d}$ & $29.0 \mathrm{~d}$ & $49.5 \mathrm{c}$ & \\
\hline $\mathbf{M}_{\mathbf{B}}$ & $38.1 \mathrm{c}$ & $44.4 \mathrm{~b}$ & $65.0 \mathrm{a}$ & -- & $44.2 \mathrm{c}$ & 54.9 b & $70.4 \mathrm{a}$ & \\
\hline \multirow{4}{*}{$\begin{array}{l}13^{\text {th }} \text { April } \\
1^{\text {th }} \text { May } \\
13^{\text {th }} \text { Jun }\end{array}$} & \multicolumn{8}{|c|}{ Stem $(g)$} \\
\hline & $292.2 d$ & $333.0 \mathrm{~b}$ & $378.0 \mathrm{a}$ & $334.4 \mathrm{a}$ & $391.4 \mathrm{~b}$ & $440.3 \mathrm{a}$ & $449.3 \mathrm{a}$ & \multirow{3}{*}{$\begin{array}{l}427.0 \mathrm{a} \\
383.6 \mathrm{~b} \\
277.8 \mathrm{c} \\
\end{array}$} \\
\hline & $247.8 \mathrm{e}$ & $297.9 \mathrm{~cd}$ & $314.3 \mathrm{bc}$ & $286.6 \mathrm{~b}$ & $308.8 \mathrm{c}$ & $394.2 \mathrm{~b}$ & $447.8 \mathrm{a}$ & \\
\hline & $99.3 \mathrm{f}$ & $278.3 \mathrm{~d}$ & $293.9 \mathrm{~d}$ & $223.8 \mathrm{c}$ & $235.8 \mathrm{e}$ & $276.0 \mathrm{~d}$ & $321.5 \mathrm{c}$ & \\
\hline $\mathbf{M}_{\mathrm{B}}$ & 213.1 b & $303.0 \mathrm{a}$ & $328.7 \mathbf{a}$ & & $312.0 \mathrm{c}$ & $370.1 \mathrm{~b}$ & $406.2 \mathrm{a}$ & \\
\hline \multirow{4}{*}{$\begin{array}{l}13^{\text {th }} \text { April } \\
1^{\text {th }} \text { May } \\
13^{\text {th }} \text { Jun }\end{array}$} & \multicolumn{8}{|c|}{ Roots $(g)$} \\
\hline & $31.3 \mathrm{c}$ & $28.1 \mathrm{~d}$ & $38.5 \mathrm{a}$ & $32.6 \mathrm{a}$ & $33.8 \mathrm{~d}$ & $42.1 \mathrm{~b}$ & $44.8 \mathrm{a}$ & \multirow{3}{*}{$\begin{array}{l}40.2 \mathrm{a} \\
36.7 \mathrm{~b} \\
28.7 \mathrm{c}\end{array}$} \\
\hline & $26.6 \mathrm{~d}$ & $31.8 \mathrm{c}$ & $36.0 \mathrm{~b}$ & $31.5 \mathrm{a}$ & $32.5 \mathrm{~d}$ & $37.3 \mathrm{c}$ & $40.4 \mathrm{~b}$ & \\
\hline & $22.2 \mathrm{e}$ & $32.3 \mathrm{c}$ & $28.5 \mathrm{~d}$ & $27.6 \mathrm{~b}$ & $26.1 \mathrm{f}$ & $29.8 \mathrm{e}$ & $30.3 \mathrm{e}$ & \\
\hline $\mathbf{M}_{\mathrm{B}}$ & $26.7 \mathrm{c}$ & $30.7 \mathrm{~b}$ & $34.3 \mathrm{a}$ & -- & $30.8 \mathrm{~b}$ & $36.4 \mathrm{a}$ & $38.5 \mathrm{a}$ & \\
\hline
\end{tabular}


delay sowing time to $13^{\text {th }}$ June. In the same time, the vernalization treatment of $10^{\circ} \mathrm{C}$ gave the heaviest and significant differences of fresh and dry weights of leaves, stem and root/plant, compared with other vernalization treatments, during the two seasons.

Concerning the interaction treatments between previous factors, the combined treatment of sowing date at $13^{\text {th }}$ Aril and seed cooling with $10^{\circ} \mathrm{C}$ resulted the highest values of fresh and dry weights of leaves, stem and root/plant, in the first and second seasons.

\section{Number of fruits/plant}

The data tabulated in Table (7) show the effect of sowing dates, seed cooling temperature and their interaction on number of fruits/plant, and indicated that, the number of fruits decreased with delaying sowing date, which the highest number was obtained when the seeds sown in $13^{\text {th }}$ April with significant differences with other dates. The first sowing date raised the number of fruits/plant more than 12.7 and $25.4 \%$ in the first season, and more than 13.0 and $16.2 \%$ in the second one, over $13^{\text {th }}$ May and $13^{\text {th }}$ Jun, respectively.

As for the effect of seed cooling temperature, the results showed that, the treatment of cooling temperature of $10^{\circ} \mathrm{C}$ gave the highest number of fruits/plant. It's raised the value more than 21.6 and $73.7 \%$, in the first season, and more than 25.7 and $49.9 \%$, in the second one, over the $5^{\circ} \mathrm{C}$ and room treatments, respectively.

\section{The calyx yield:}

It should be pointed out that, the data in Table (7) and showed in Figure (1) indicate that, the calyx dry weight per plant significantly higher in sowing time at April $13^{\text {th }}$ which recorded (26.1 and $24.7 \mathrm{~g} / \mathrm{plant}$ ) in 2012 and 2013 respectively. This treatment had significant increase with the other sowing dates.

Concerning the effect of seed cooling treatments, the data tabulated in Table (6) and illustrated in Figure (1) state that, the highest dry weight of calyx/plant was obtained from plants cooled under temperature of $10^{\circ}$. The other treatments (Room and $5^{\circ}$ degree) gave the greatest value in this concern. These results repeated in the two seasons. The treatment of $10^{\circ} \mathrm{C}$ raised the dry weight of calyx more than 26.5 and $55.4 \%$, in the first season, and more than 22.5 and $63.8 \%$, in the second one, over the $5^{\circ} \mathrm{C}$ and room treatments, respectively. 
Table (7):Effect of sowing date, seed cooling temperature and their interaction treatments on number of fruits/plant, calyx dry weight $(\mathrm{g}) /$ plant and anthocyanin content $(\%) /$ plant of roselle plants during 2012 and 2013 seasons.

\begin{tabular}{|c|c|c|c|c|c|c|c|c|}
\hline \multirow{3}{*}{ 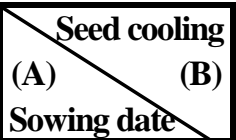 } & Room & $5^{\circ} \mathrm{C}$ & $10^{\circ} \mathrm{C}$ & $\mathbf{M}_{\mathrm{A}}$ & Room & $5^{\circ} \mathrm{C}$ & $10^{\circ} \mathrm{C}$ & $\mathbf{M}_{\mathbf{A}}$ \\
\hline & \multicolumn{4}{|c|}{ First season } & \multicolumn{4}{|c|}{ Second season } \\
\hline & \multicolumn{8}{|c|}{ Number of fruits/plant } \\
\hline \multirow{3}{*}{\begin{tabular}{|c|}
$13^{\text {th }}$ April \\
$13^{\text {th }}$ May \\
$13^{\text {th }}$ Jun \\
\end{tabular}} & $50.5 \mathrm{~cd}$ & $68.5 \mathrm{bc}$ & $94.0 \mathrm{a}$ & $71.0 \mathrm{a}$ & $62.1 \mathrm{e}$ & $69.5 \mathrm{c}$ & $94.5 \mathrm{a}$ & $75.4 \mathrm{a}$ \\
\hline & $49.8 \mathrm{~d}$ & $64.3 \mathrm{c}$ & $75.0 \mathrm{~b}$ & 63.0 b & $54.0 \mathrm{f}$ & $66.5 \mathrm{~cd}$ & $79.5 \mathrm{~b}$ & $66.7 \mathrm{~b}$ \\
\hline & $37.0 \mathrm{e}$ & $63.3 \mathrm{c}$ & $69.5 \mathrm{bc}$ & $56.0 \mathrm{c}$ & $52.0 \mathrm{f}$ & $64.5 \mathrm{de}$ & $78.0 \mathrm{~b}$ & $64.8 \mathrm{~b}$ \\
\hline $\mathbf{M}_{\mathrm{B}}$ & $45.8 \mathrm{c}$ & $65.4 \mathrm{~b}$ & $79.5 \mathrm{a}$ & & $56.0 \mathrm{c}$ & $66.8 \mathrm{~b}$ & $84.0 \mathrm{a}$ & \\
\hline \multirow{4}{*}{$\begin{array}{l}13^{\text {th }} \text { April } \\
13^{\text {th }} \text { May } \\
13^{\text {th }} \text { Jun }\end{array}$} & \multicolumn{8}{|c|}{ Calyx dry weight (g)/plant } \\
\hline & $17.8 \mathrm{cde}$ & $25.0 \mathrm{~b}$ & $35.6 \mathrm{a}$ & $26.1 \mathrm{a}$ & $19.9 \mathrm{~d}$ & $23.6 \mathrm{c}$ & $30.7 \mathrm{a}$ & 24.7 a \\
\hline & $16.3 \mathrm{de}$ & $19.5 \mathrm{~cd}$ & $20.5 \mathrm{c}$ & $18.8 \mathrm{~b}$ & $15.5 \mathrm{e}$ & $22.5 \mathrm{c}$ & $26.2 \mathrm{~b}$ & $21.4 \mathrm{~b}$ \\
\hline & $14.9 \mathrm{e}$ & $15.7 \mathrm{e}$ & $20.1 \mathrm{c}$ & $16.9 \mathrm{c}$ & $15.2 \mathrm{e}$ & $21.5 \mathrm{~d}$ & $26.0 \mathrm{~b}$ & $20.9 \mathrm{~b}$ \\
\hline$\overline{M_{B}}$ & $16.3 \mathrm{c}$ & $20.1 \mathrm{~b}$ & $25.4 \mathrm{a}$ & & $16.9 \mathrm{c}$ & $22.5 \mathrm{~b}$ & $27.6 \mathrm{a}$ & \\
\hline \multirow{4}{*}{$\begin{array}{l}13^{\text {th }} \text { Appril } \\
13^{\text {th }} \text { May } \\
13^{\text {th }} \text { Jun } \\
\end{array}$} & \multicolumn{8}{|c|}{ Anthocyanin (\%) } \\
\hline & $4.50 \mathrm{~b}$ & $4.93 \mathrm{ab}$ & $4.97 \mathrm{a}$ & $4.80 \mathrm{a}$ & $4.44 \mathrm{bc}$ & $4.91 \mathrm{ab}$ & $4.96 \mathrm{a}$ & $4.77 \mathrm{a}$ \\
\hline & $3.48 \mathrm{c}$ & $4.18 \mathrm{~b}$ & $4.48 \mathrm{~b}$ & $4.05 \mathrm{~b}$ & $4.16 \mathrm{~cd}$ & $4.26 \mathrm{c}$ & $4.32 \mathrm{bc}$ & $4.25 \mathrm{~b}$ \\
\hline & $3.35 \mathrm{c}$ & $3.61 \mathrm{c}$ & $3.68 \mathrm{c}$ & $3.55 \mathrm{c}$ & $3.48 \mathrm{e}$ & $3.62 \mathrm{de}$ & $3.71 \mathrm{de}$ & $3.60 \mathrm{c}$ \\
\hline$\overline{M_{B}}$ & $3.78 \mathrm{~b}$ & $4.24 \mathrm{a}$ & $4.38 \mathrm{a}$ & & $4.03 \mathrm{~b}$ & $4.26 \mathrm{a}$ & $4.33 \mathrm{a}$ & \\
\hline
\end{tabular}

The calyx dry weight (g)/plant was highest and significant value with the interaction treatment of sowing date at April $13^{\text {th }}+$ seed cooling with $10^{\circ}$ degreetreatment during the two seasons, as mentioned in Table 6 .

As in the previous set of experiments, higher dry weight of calyx per plant was associated with higher fresh and dry weights of stem and root, on contrast with later sowing time, the lower calyx yield were associated with lower vegetative growth and the plants being small. These results agree with those reported by Castro et al. (2004) who found that, the yield of vinegar plant calyxes reduction as sowing was delayed.

The cycle of plants, via the number of days from sowing to harvest was different at sowing dates. April enabled a longer cycle (210) days, May provided a (180) day cycle and June only (150) days. The longest cycles occurred in the sowing date of April than the sowing of June presupposing that vegetative period is to occur on days where there is greater number of hours light, supporting increased growth of plants and hence higher yields (Castro et al., 2004). 


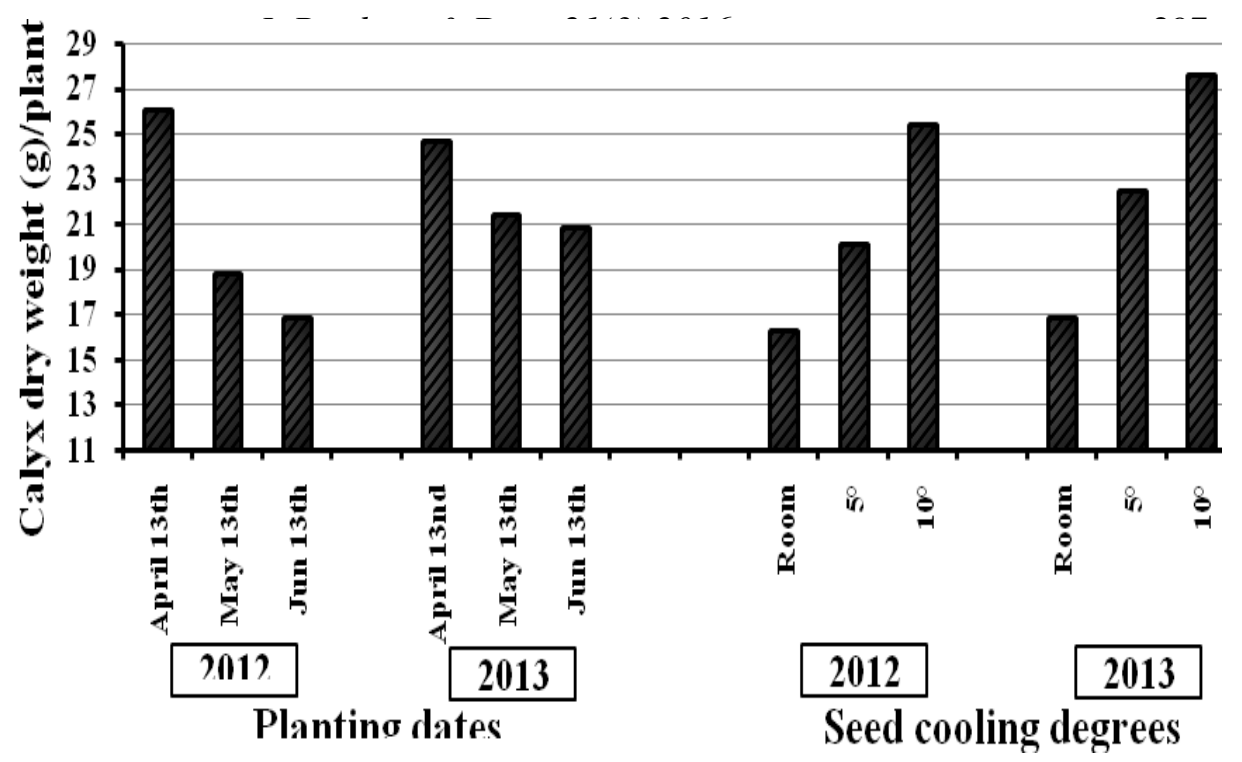

Figure (1): Effect of sowing dates and seed cooling degrees treatments on calyx dry weight (g)/plant in roselle plants during 2012 and 2013 seasons.

\section{Anthocyanin (\%):}

The concentrations of anthocyanin were given in Table (7) and illustrated in Figure 2. Results indicate that, anthocyanin content of roselle calyxes were significantly increased with bringing forward sowing time in April, and gradually decreased from May to Jun. The maximum concentration of anthocyanin was developed when the Roselle plant growing in $13^{\text {th }}$ Aprillwhich gave 4.8 and $4.77 \%$, in the two seasons, respectively, while the minimum concentration of anthocyanin was produced in the plant time $13^{\text {th }}$ Jun in both seasons. The decreased of the concentration of plant product by delay in sowing date was recorded by (Rehman , 2014) on strawberry .

The treatments of seed cooling degrees were recorded in Table (7) and stated in Fig (2) and reveal that, the treatment of $10^{\circ} \mathrm{C}$ resulted the highest and significant concentration of anthocyanin (\%) in roselle plant comparing with (room) treatment, while there was no significant between the seed cooling degree treatments of $5^{\circ}$ and $10^{\circ} \mathrm{C}$ during the two seasons.

The effect of interaction treatments between sowing dates and seed cooling degrees on anthocyanin content in Roselle plants was significant, as shown in Table (7). The highest concentration was recorded from the interaction treatment of April $13^{\text {th }}+10^{\circ}$ seed cooling temperature, during the $1^{\text {st }}$ and $2^{\text {nd }}$ seasons. 


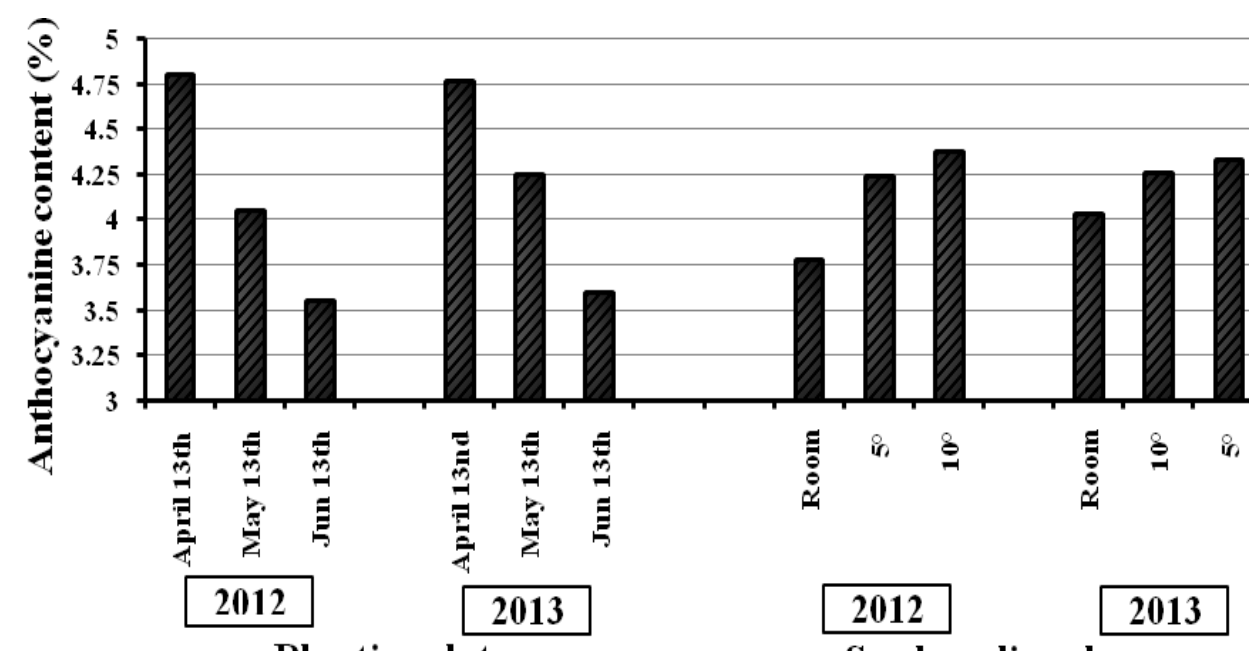

Planting dates

Seed cooling degrees

Figure (2): Effect of sowing dates and seed cooling degrees treatments on anthocyanin (\%) in Roselle plants during 2012 and 2013 seasons.

Conclusively, it could be concluded that, sowing of roselle at early time $\left(13^{\text {th }}\right.$ April) and treated of seeds under $10^{\circ} \mathrm{C}$ was the best treatment for enchanting plant growth, yield of calyx and highest percentage of anthocyanin under sandy soil conditions .

\section{REFERENCES}

Akindahunsi, A. A. and M. T. Olaleye (2003): Toxicological investigation of aqueous-methanolic extract of the calyces of Hibiscus sabdariffa L. Journal of Ethnophar., 89, 161-164.

Board, J. E.; M. S. Kang and B. G. Harville (1999): Path analysis of the yield formation process for late-planted soybean. Agro. Journal, 91: 128-135.

Boquet, D. J. (1990): Plant population density and row spacing effects on soybean at post-optimal sowing dates. Agro. Journal, 82: 59-64.

Castro, N. ; J. Pinto; M. Cardoso : R. Augusto ; S. Bertolucci ; F. Silva and F. Delú (2004): Sowing time for maximization of yield of vinegar plant calyx (Hibiscus sabdariffa L.). Ciênc. agrotec., Lavras, 28 (3): 542-551.

Cissé, M.; M. Dornier; M. Sakho; A. N'Diaye; M. Reynes and O. Sock (2009): Le bissap (Hibiscus sabdariffa L.): composition et principales utilisations. Fruits, 64 (3): 179-193 
Dielen, V.; C. Notté;S. Lutts; V. Debavelaere; J. Van Herck and J. Kinet (2005): Bolting control by low temperatures in root chicory (Cichoriumintybus var. sativum). Field Crops Research, 94 (1): 7685.

Du, C. T. and F. J. Francis (1973): Anthocyanin of roselle. Journal of Food Sci ., 38: 810-820.

Engelen-E. G. and J. E. Erwin (1997): A model plant for vernalization studies. Scientia Horticulturae, 70 (2-3): 197-202.

Fuleki S. and F. Francis (1968): Quantitative methods of anthocyanin 1.Extraction and determination of anthocyanin in cranberries. Journal of Food Sci., 33:72.

Garner, M. J. and M.A. Armitage (1998): Influence of cooling and photoperiod on growth and flowering of Aquilegia L. cultivars. Scientia Hort., 75(1-2): 83-90.

Kantolic, A.G. and G. A.Slafer(2001): Photoperiod sensitivity after flowering and seed number determination in indeterminate soybean cultivars. Field Crops Res., 72, 109-118.

Naeve, S.L.; B. D. Potter; S. R. Quiring; T. A. O'Neil and J. E. Kurle(2004): Influence of soybean plant population and row spacing on development and yield across sowing dates in Minnesota. Available at www. soybeans. umn. Ed up dfs /2004 asaposter _1_spacingsowing_screen.pdf(verified11Dec.2007)University of Minnesota Minneapolis.

Rahman M. (2014) Interaction effect of sowing date and cultivars on plant height, number of leaves and plant mortality in strawberry. Journal of Horticulture and Forest, 3:31-37.

Reda, F.; M. S. Fadl; R. S. Abdel-All and, A. El-Moursi (1977): The effect of vernalization on growth and chromone pattern of the medicinal Ammi visnaga L. Scientia-Hort., 7(2): 107-114.

Rehman M.: K. Tasneem ; A. Ashfaq : A. W. Syed and H. Saddam (2014):Effect of Sowing Time and Cultivar on Soybean Performance in Semi-Arid Punjab, Pakistan Global Journal of Science Frontier Research: D Agriculture and Veterinary, 14(3).

Statsoft, Inc. (2001): STATISTICA fur Windows (software-system fur Datenanalyse) Version 6. http: $\backslash W W W$. Statisoft. Com.

Tom, V.; J. H. Rodolfo; E. S. James and W. Qing-Li (2013): ACS Symposium Series, 1127 (14): 209- 230. 
النمو والمحصول فى الكركديه وتأثرهما بموعد الزراعة وتبريد البذور عزت غنيم إسماعيل قسم النباتات الطبية و العطرية ، معهد بحوث البساتين ، مركز البحوث الزر اعية ،

أجريت در اسة حقلية على نبات الكركديه صنف صباحية V ا اخلال الموسمين

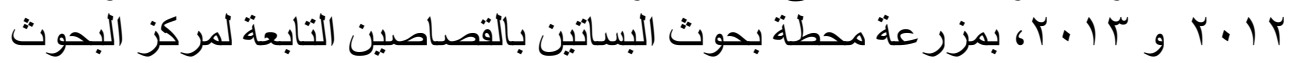

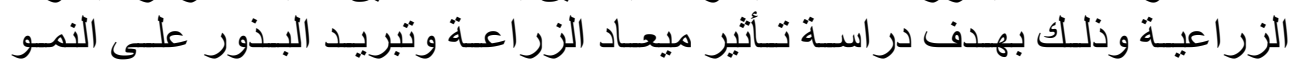

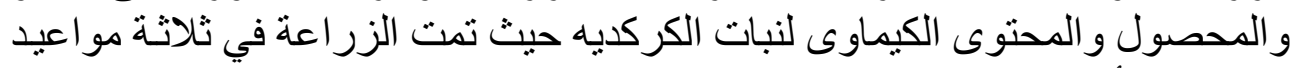

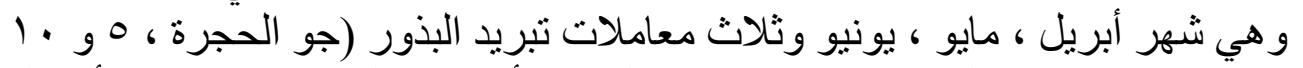

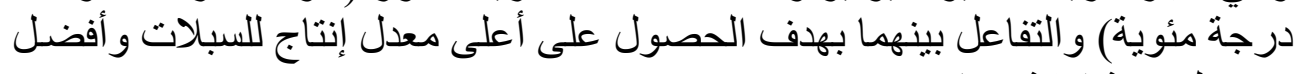

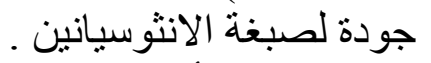

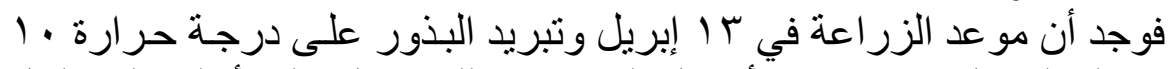

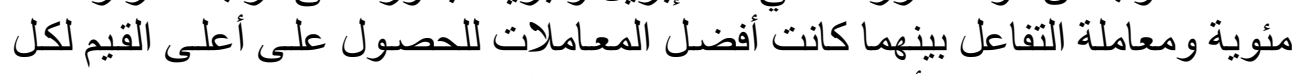

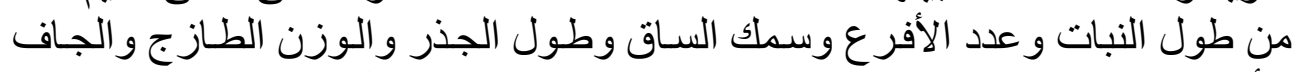

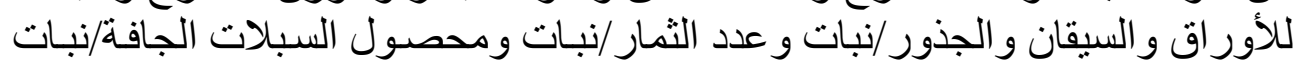

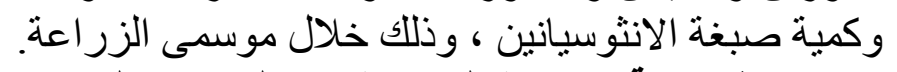

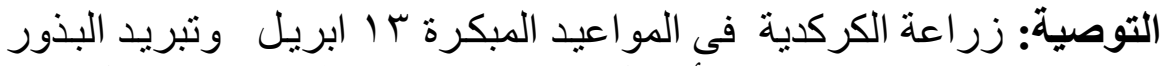

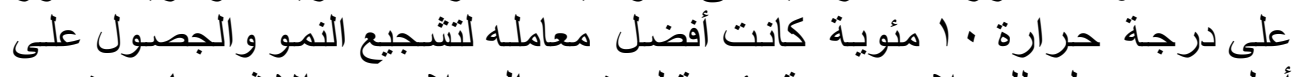

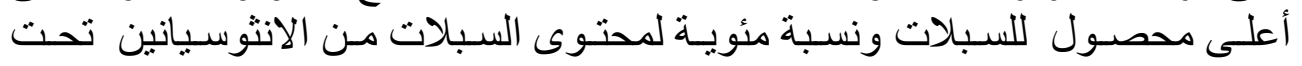

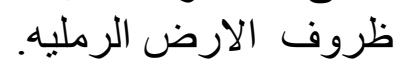

